\title{
Film deposition and annealing treatment of sputtered bismuth telluride based thin films \\ スパッタリング法によるビスマステルライド系薄膜熱電素子の成膜およびアニール処理
}

\author{
Yusuke SASAKI, Ken TAKAYAMA and Masayuki TAKASHIRI \\ Department of Materials Science, School of Engineering, Tokai University, 4-1-1 Kitakaname, \\ Hiratsuka, Kanagawa, 259-1292 Japan
}

TEL: +81-463-58-1211(EX.4203) FAX: +81-463-50-2096 e-mail: takashiri@tokai-u.jp

(Received 9 March, $2015 \quad$ Accepted 10 April, 2015)

In an effort to fabricate thin film thermoelectric generators, we prepared p-type antimony telluride and n-type bismuth telluride thin films by using a RF magnetron sputtering, after which a thermal annealing was implemented. We investigated the relationship between the annealing temperatures and the properties of both types of the thin films. The structural properties were analyzed by x-ray diffraction patterns and scanning electron microscope. The in-plane electrical properties, which were the electrical conductivity, Seebeck coefficient and power factor, were estimated at room temperature. As a result, the surface morphology of both types of the thin films exhibited nano-sized pores as the annealing temperature increased possibly because of the evaporation of tellurium atoms. This evaporation also induced to increase the defect density of both types of the thin films, and to be degraded their electrical properties. Therefore, we resulted in the higher thermoelectric properties at the annealing temperature of $300^{\circ} \mathrm{C}$; antimony telluride: $\sigma S^{2}=18.8 \mu \mathrm{W} /(\mathrm{cm}$ $\cdot \mathrm{K}^{2}$ ) and bismuth telluride: $\sigma S^{2}=20.9 \mu \mathrm{W} /\left(\mathrm{cm} \cdot \mathrm{K}^{2}\right)$.

Keywords : Bismuth telluride based thin films, Sputtering, Annealing treatment

\section{INTRODUCTION}

熱電変換素子の材料開発の歴史は長く，1950年代にそ の端を発し，それ以降，脈々と研究開発が続けられてい る. 1 熱電変換素子の最大の魅力は熱を電気に, または 電気を熱に直接変換ができることである．熱から電気へ の変換はゼーベック効果であり, 電気から熱への変換は ペルチェ効果によるものである，熱電変換素子を利用し たデバイスはP型素子と $\mathrm{N}$ 型素子の 2 種類から成り，それ らを直列に接続した構造になっている.デバイスの発 電・冷却性能の優劣は熱電素子材料の特性に左右される. その材料性能を示す評価方法の 1 つとしてパワーファク ターP.F.があり，P.F.= $S^{2} \sigma て ゙$ 表せる.ここでSはゼーベッ ク係数, $\sigma$ 電気伝導率である.

特に熱電発電デバイスは，東日本大震災による原発事 故により再生可能エネルギーを使った発電技術の一つと して注目を集めている。この熱電発電技術の利用方法は

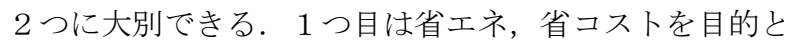
した熱エネルギー回収発電としての利用であり，もう 1 つはわずかな環境中の温度差を利用した微小電力発電に おける利用である。前者では，モジュール価格や発電効
率，寿命により発電システムの経済性が決まるため, 熱 電材料の性能向上が強く望まれる状況である。一方，後 者の微小電力発電技術は半導体産業が得意としてきた量 産技術によるデバイスの低コスト化が重要であり，超低 消費電力のアプリケーション開発の進展に伴い, 今後大 きな市場の創成が期待できる．例えば，航空機の故障診 断におけるワイヤレスセンサシステムへの利用などセン サ電源への用途が注目されている.2

このように微小温度差で発電できるデバイスを作製す る上で最も重要な技術は，薄膜の成膜技術と熱電材料の 選択である. 薄膜熱電素子の成膜方法には, スパッタリ ング法，3 めっき法，4 フラッシュ蒸着法 5 などがある. 中でもスパッタリングは基板への密着力の強い薄膜の作 製や合金系のターゲットの組成比をほぼ保ったまま薄膜 の作製が可能である.

熱電材料に関しては, 使用できる温度域によって様々 な材料が提案されている。このうち室温付近で最も高い 性能を示す熱電材料はビスマス-テルライド系合金であ る. ${ }^{6} こ の$ 材料は六方晶の構造を持っており，単位胞に は18個のビスマス原子と27個のテルル原子が含まれる. 
このビスマステルル材料は本来はN型の半導体特性を示 すが, ビスマス原子をアンチモン原子に置換することでP 型半導体になる. このように, 同じ構造を持った材料で $\mathrm{N}$ 型， $\mathrm{P}$ 型を制御できることは熱電デバイスを作製する上

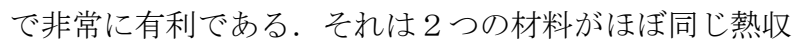
縮・膨張特性を持つことから，デバイスに温度差を負荷 しても破壊されにくいためである.

本研究では，ビスマステルライド系薄膜熱電デバイス の作製を最終的な目標として，N型ビスマステルル膜 (Bi-Te) とP型アンチモンテルル $(\mathrm{Sb}-\mathrm{Te})$ 薄膜をRFマグネト ロンスパッタ法を用いて作製した。成膜後, 薄膜物性の 改善のためにアニール処理を行った. 薄膜の評価は構造 的特性と電気的特性の両面から実施した。

\section{EXPERIMENTAL}

まず, $\mathrm{P}$ 型のアンチモンテルル(Sb-Te)およびN型のビス マステルル $(\mathrm{Bi}-\mathrm{Te})$ 薄膜熱電素子を RFマグネトロンスパ ッタリング装置(Tokuda, CFS-8EP)を用いて成膜した。 タ ーゲットはP型薄膜の成膜では直径4インチの高純度 (99.9\%)ターゲット Sb(40 at.\%)-Te(60 at.\%)(高純度化学研 究所製)を用い，N型では直径4インチの高純度(99.9\%)夕 ーゲットBi(30 at.\%)-Te(70 at.\%)(高純度化学研究所製)を 使用した。 基板はガラス基板(EAGLE XG) (縦 : $30 \mathrm{~mm}$, 横: $20 \mathrm{~mm}$, 厚さ: $1.1 \mathrm{~mm}$ )を使用した. 成膜条件として, 雰囲気ガスは高純度Arガスであり, 成膜圧力は $1.0 \mathrm{~Pa}$ とし た. 印加RFパワーは $200 \mathrm{~kW} と し$, 基板加熱は行っていな い. また膜厚の均一性を保つために, 基板ホルダーを20 $\mathrm{rpm}$ で回転させた。成膜時間は60分間とし，得られた膜 厚は約 $0.5 \mu \mathrm{m}$ であった.

アニール処理は電気炉を用いて行った．雰囲気ガスと して $\mathrm{Ar}(95 \%)-\mathrm{H}_{2}(5 \%) を$ 用いた。アニール温度は $200^{\circ} \mathrm{C}$, $300^{\circ} \mathrm{C}, 400^{\circ} \mathrm{C}$ し, 昇温は $4 \mathrm{~K} / \mathrm{min}$ で行い, 所定のアニー ル温度で60分間保持した.アニール処理後, 炉内の温度 が $100^{\circ} \mathrm{C}$ 以下になるまで雾囲気ガスを流し続け試料を取 り出した.

次に，構造的特性として走查型電子顕微鏡(SEM)によ る表面観察とX線回折による結晶学特性を評価した。結 晶粒径はX線回折を用いて得られた回折強度の半值幅か らシェラーの式を用いて平均結晶粒径を算出した。7 電気的特性として電気伝導率 $\sigma$, ゼーベック係数 $S$ とパワ ーファクターP.F. $\left(P . F .=S^{2} \sigma\right)$ を室温で評価した. 電気伝導 率の測定には4端子抵抗測定装置(NAPSON, RT-70V)を用 いた．ゼーベック係数の測定では，ヒートシンクとヒー 夕間に作製した試料を置き，その表面にK熱電対を固定 し，膜面方向に温度差を0〜 $4 \mathrm{~K}$ 与えたときに発生する 熱起電力から算出した。 得られた熱起電力には $\mathrm{K}$ 熱電対 の材料であるアルメルとクロメルの熱起電力を含んでい るため, その分を差し引いて熱電薄膜のみのゼーベック
係数を算出した. パワーファクターP.F.は得られた電気 伝導率 $\sigma$ とゼーベック係数Sから算出した.

\section{RESULTS AND DISCUSSION}

図1にSb-Te薄膜およびBi-Te薄膜の表面SEM像を示す. $\mathrm{Sb}-\mathrm{Te}$ 薄膜では, アニール温度 $200^{\circ} \mathrm{C}$ ま゙凸凸のない表面

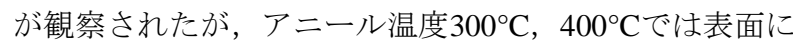
小さな空孔が見られた。同様にBi-Te薄膜においても $\mathrm{Sb}-\mathrm{Te}$ 薄膜と同じくアニール温度 $200^{\circ} \mathrm{C}$ まで凹のない表 面が観察されたが，アニール温度 $300^{\circ} \mathrm{C}, 400^{\circ} \mathrm{C}$ は表面に 小さい空孔が観察された。このようにSb-Te薄膜および $\mathrm{Bi}-\mathrm{Te}$ 薄膜どちらの薄膜においてもアニール温度 $300^{\circ} \mathrm{C}$ 以 上で構造に大きな変化が生じた。この原因として, Te原
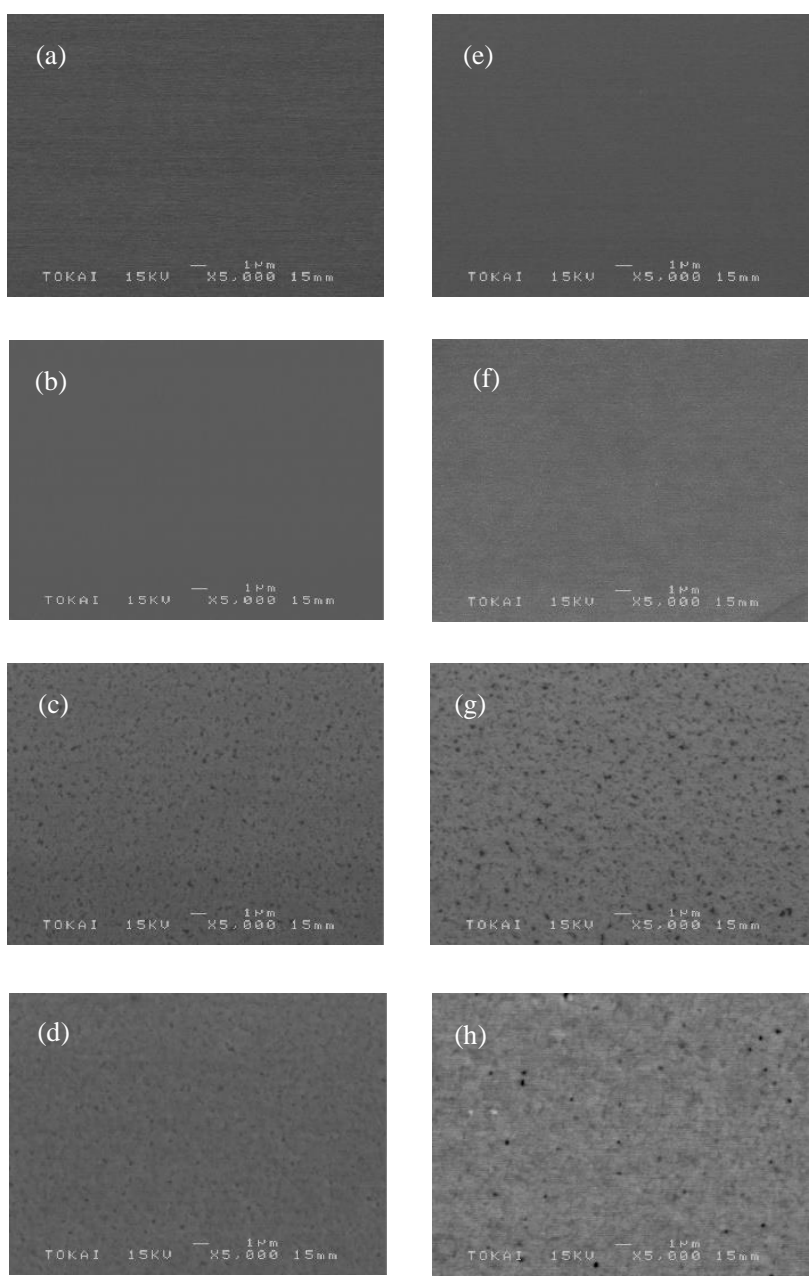

Fig. 1. Surface morphologies of p-type Sb-Te and n-type Bi-Te thin films on glass substrates imaged using SEM. (a)-(d) are images of $\mathrm{Sb}-\mathrm{Te}$ films that were unannealed sample, annealed samples of $200^{\circ} \mathrm{C}, 300^{\circ} \mathrm{C}$, and $400^{\circ} \mathrm{C}$, respectively. (e)-(h) are images of $\mathrm{Bi}-\mathrm{Te}$ thin films that were unannealed sample, annealed samples of $200^{\circ} \mathrm{C}$, $300^{\circ} \mathrm{C}$, and $400^{\circ} \mathrm{C}$, respectively. 
子が薄膜から蒸発した影響であると考えられる.

図2にSb-Te薄膜およびBi-Te薄膜のX線回折結果を示す。 Sb-Te薄膜では, アニール処理を行った薄膜は(0 1 15$)$, (1 0 10)に強い回折ピークを示した. また，アニール温度が高 いほど強い回折ピークを示した。しかし，アニール処理 を行ってない試料は回折ピークが見られなかった。これ は，この薄膜がアモルファス構造であることを示してい る. Bi-Te薄膜では, アニール処理を行った薄膜は(0 015$)$,

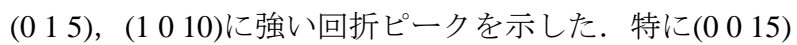
はアニール温度が高くなるほど強い回折ピークを示した。 これはアニール温度を高めることで $c$ 軸配向が進行して いることを示す.

図3にSb-Te薄膜およびBi-Te薄膜の平均結晶粒径とア ニール温度の関係を示す. 平均結晶粒径はSb-Te薄膜およ びBi-Te薄膜のX線回折から得られた(0 1015$)$ の回折ピーク の半值幅から算出した. Sb-Te薄膜において, アニール未 処理の薄膜はアモルファス状であるため, 結晶粒径を0 $\mathrm{nm}$ とした. Sb-Te薄膜ではアニール温度が $300^{\circ} \mathrm{C}$ まで結晶 粒径が大きくなる傾向があり, 最大結晶粒径は97 nmであ った。それ以降のアニール温度では, 結晶粒径はわずか な減少が見られた。同様に, Bi-Te薄膜においてもアニー ル温度が $300^{\circ} \mathrm{C}$ ま゙結晶粒径が大きくなる傾向があり, 最 大結晶粒径は94 nmであった. それ以降のアニール温度で は，結晶粒径はわずかな減少が見られた．Sb-Te薄膜と $\mathrm{Bi}-\mathrm{Te}$ 薄膜で同様の傾向を示す理由はどちらもビスマス テルライド系六方晶の結晶構造を持っているからだと考 えられる.また, 両者ともに $400^{\circ} \mathrm{C} て ゙$ 結晶粒径が少し小さ
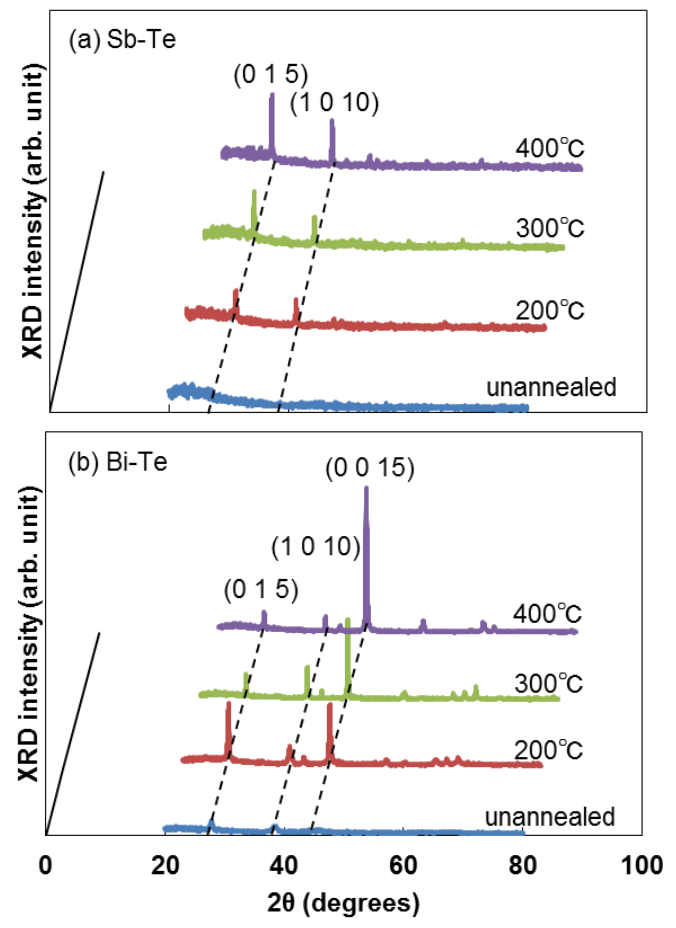

Fig. 2. X-ray diffraction patterns of p-type $\mathrm{Sb}$-Te and n-type Bi-Te thin films.
くなった。これはTe原子の蒸発したことが原因であると 考えられる.

図4にSb-Te薄膜およびBi-Te薄膜の電気伝導率 $\sigma$, ゼー ベック係数 $S$, パワーファクターP.F.とアニール温度の関 係を示す. Sb-Te薄膜の電気伝導率は, アニール未処理と $200^{\circ} \mathrm{C}$ でアニール処理したサンプルの電気伝導率が非常 に小さい值になった。これはアモルファス成分が電子輸 送を妨げているためであると考えられる.

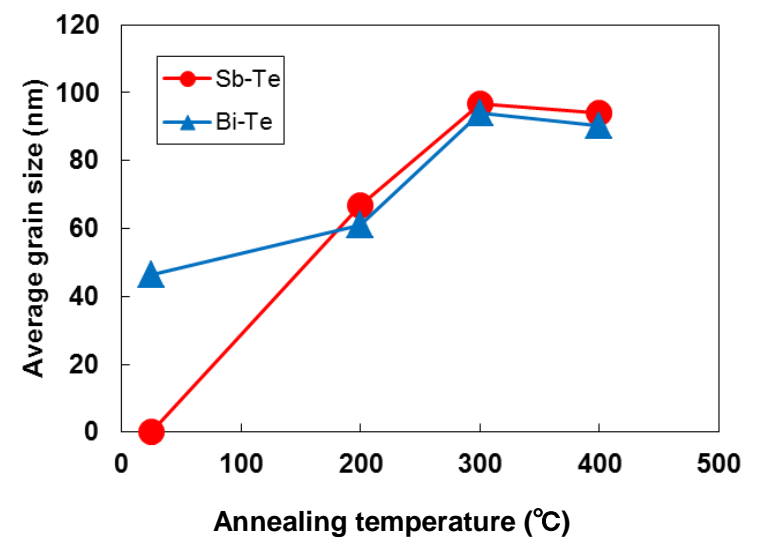

Fig. 3. Average grain size of p-type Sb-Te and n-type $\mathrm{Bi}-\mathrm{Te}$ thin films as a function of annealing temperature.

アニール温度をそれ以上にすると, Sb-Te薄膜の電気伝導 率は急激に上昇し，最大值はアニール温度 $400^{\circ} \mathrm{C}$ で 3481 $\mathrm{S} / \mathrm{cm}$ になった。一方, Bi-Te薄膜の電気伝導率に関して, アニール未処理サンプルの電気伝導率はSb-Te膜と同様 に非常に低い值を示した。この原因はBi-Te薄膜と Sb-Te 薄膜で同じであると考えられる。しかし，アニール温度 を $200^{\circ} \mathrm{C} に し た$ 時, Bi-Te薄膜の電気伝導率は比較的高い 值を示した。これはBi-Te薄膜がSb-Te薄膜よりも低温で 結晶化が進行していることを示す。さらにアニール温度

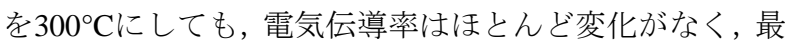
大值はアニール温度 $300^{\circ} \mathrm{C}$ で $862 \mathrm{~S} / \mathrm{cm}$ になった。らにア ニール温度を $400^{\circ} \mathrm{C}$ で上昇させると電気伝導率は減少 した．Sb-Te薄膜とBi-Te薄膜を比較した場合，アニール 温度 $400^{\circ} \mathrm{C}$ における電気伝導率の傾向が反対になってい る.この原因として考えられることは，Te原子の蒸発に より発生した欠陥の特性の違いである。P型Sb-Teにおい て発生した欠陥はキャリアを供給する作用をしており, N型Bi-Teにおいて発生した欠陥はキャリアをトラップす る働きをしていると推測できる.8

ゼーベック係数では, P型であるSb-Te薄膜はプラスの 值に高いほどゼーベック効果が高く，0に近いほど低い. また，N型であるBi-Te薄膜はマイナスの值に高いほどゼ 一ベック効果が高く，0に近いほど低い，Sb-Te薄膜はア ニール温度 $300^{\circ} \mathrm{C}$ ま゙は大きな変化が見られず, 最大值は $150 \mu \mathrm{V} / \mathrm{K}\left(\right.$ アニール温度 $\left.300^{\circ} \mathrm{C}\right)$ になった。 さらにアニール 


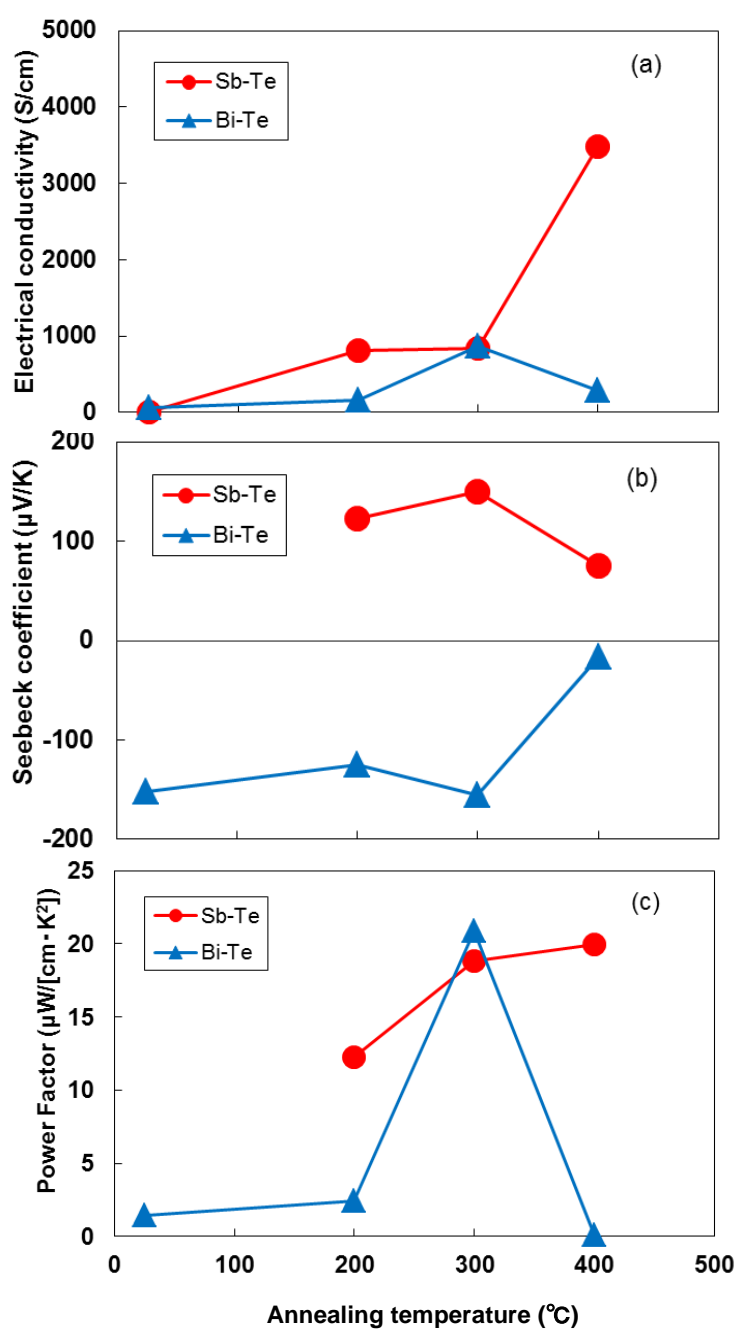

Fig. 4 (a) Electrical conductivity, (b) Seebeck coefficient, (c) power factor of p-type Sb-Te and n-type Bi-Te thin films as a function of annealing temperature.

温度を $400^{\circ} \mathrm{C}$ にするとゼーベック係数は劣化した.一般に ゼーベック係数はキャリア濃度と反比例の関係が知られ ている. 9 よって, アニール温度 $400^{\circ} \mathrm{C}$ ておけるゼーベッ ク係数の劣化は欠陥が発生したことによるキャリア濃度 の増加が原因であると考えられ，これは電気伝導率の上 昇とも現象としての整合性がある. Bi-Te薄膜のゼーベッ ク係数に関しても，同様な傾向が見られた．アニール温 度 $300^{\circ} \mathrm{C}$ まで大きな変化が見られず，最大值はで-155 $\mu \mathrm{V} / \mathrm{K}\left(\right.$ アニール温度 $300^{\circ} \mathrm{C}$ ) となった.さらにアニール温度 を $400^{\circ} \mathrm{C}$ にするゼーベック係数は大きく劣化した。こ の劣化の原因も $\mathrm{Sb}$ - Teの場合と同様に, Te原子の蒸発によ る欠陥の発生のためであると考えられる.

パワーファクターでは, Sb-Te薄膜はアニール温度が高

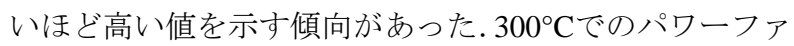
クターは $18.8 \mu \mathrm{W} /\left(\mathrm{cm} \cdot \mathrm{K}^{2}\right)$ であり, 最大值はアニール温度 $400^{\circ} \mathrm{C}$ における $20.0 \mu \mathrm{W} /\left(\mathrm{cm} \cdot \mathrm{K}^{2}\right)$ であった。 Bi-Te薄膜はア

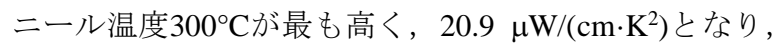
アニール温度 $400^{\circ} \mathrm{C}$ で急激に低下した.これはアニール温 度 $400^{\circ} \mathrm{C}$ での $\mathrm{Te}$ 原子の蒸発による欠陥生成の影響が $\mathrm{Bi}-\mathrm{Te}$ の方が顕著現れたためであると考えられる。

よって, 本研究の最終目標であるビスマステルライド 系薄膜熱電デバイスの作製において, アニール温度 $300^{\circ} \mathrm{C}$ が最適であると考えられる。これは，P型と $\mathrm{N}$ 型ともにア ニール温度 $300^{\circ} \mathrm{C}$ のパワファクターが高い值を示して いることと，デバイスをアニール処理する際， $\mathrm{P}$ 型と $\mathrm{N}$ 型 薄膜を同じ温度でアニール処理する方がデバイスプロセ スを簡便化できるためである.

\section{IV.CONCLUSION}

薄膜熱電デバイスの作製を最終的な目的として $\mathrm{P}$ 型 $\mathrm{Sb}-\mathrm{Te}$ 薄膜と N 型Bi-Te薄膜をRFマグネトロンスパッタ法 を用いて成膜した。成膜後, 薄膜物性の改善のためにア ニール処理を行った. Sb-TeとBi-Teの両方の薄膜におい て, アニール温度を高めると表面に小さな空孔が観察さ れた。これは薄膜表面から Te原子が蒸発したためである と考えられる．電気的特性に関しても高温アニールにお ける $\mathrm{Te}$ 蒸発が誘発した欠陥密度の上昇により, 電気伝導 率とゼーベックの值に大きな変動が見られた。よって,

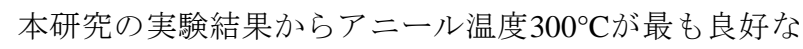
熱電性能が得られることが判明した. 今後, 熱電デバイ スの作製においては，このアニール条件をベースとする 予定である.

\section{ACKNOWLEDGMENT}

本研究の薄膜の評価・分析に協力していただいた東海 大学の喜友名浩史氏，初田直樹大学院生，草ヶ谷喬介大 学院生に感謝する.

\section{REFERENCES}

${ }^{1}$ H. J. Goldsmid and R. W. Douglas, Br. J. Appl. Phys. 5, 386 (1954).

2 D. Samson, M. Kluge, Th. Becker and U. Schmid, Sens. Actuators, A 172, 240 (2011).

${ }^{3}$ K. Kusagaya, H. Hagino, S. Tanaka, K. Miyazaki and M. Takashiri, J. Electron. Mater. DOI: 10.1007/s11664-014-3496-4 (2014).

${ }^{4}$ N. Hatsuta, K. Matsuoka and M. Takashiri, J. Adv. Sci. 25, 22 (2013).

5 M. Takashiri, T. Shirakawa, K. Miyazaki and H. Tsukamoto, Trans. Jpn. Soc. Mech. Eng., Ser. A 72, 1793 (2006). 
${ }^{6}$ D. M. Rowe, CRC handbook of Thermoelectrics, (CRC press ISBN 0-8493-0146-7, 1995), pp. 211-256.

${ }^{7}$ V. Uvarov and I. Popov, Mater. Charact. 58, 883 (2007).
${ }^{8}$ C.-N. Liao and T.-H. She, Thin Solid Films 515, 8059 (2007).

${ }^{9}$ G. J. Snyder and E. S. Toberer, Nat. Mater. 7, 105 (2008). 